\title{
ІННОВАЦІЙНІ ТЕХНОЛОГІЇ НАВЧАННЯ В ДЕРЖАВНИХ ЗАКЛАДАХ ДОШКІЛЬНОЇ ОСВІТИ: ТЕОРЕТИЧНИЙ АСПЕКТ
}

\begin{abstract}
Анотація. Кожна інноващійна педагогічна технологія обов’язково впливає на внутрішне середовище закладу дошкільної освіти, і вимагае адаптації до змін як самого закладу, так і самих дошкільних педагогів. Стаття присвячена аналізу актуального питання сьогодення - впровадження інноваційних технологій навчання в державних закладах дошкільної освіти та розкриває сутність інноваційної педагогічної діяльності як особливого виду творчої діяльності дошкільного педагога. У статті висвітлюеться та теоретично обгрунтовуеться проблема розкриття теоретичних основ важливості даної проблеми. Розкрито основні поняття «інновації», «інноваційні технології навчання», проаналізовано особливості інноващійних процесів у закладі дошкільної освіти. Здійснено аналіз інноващійних технологій організації методичної роботи в закладі дошкільної освіти.
\end{abstract}

Ключові слова: готовність дошкільного педагога до інноваційних технологій, дошкільні педагоги, заклади дошкільної освіти, інновація, інноваційні технології навчання, методична робота.

Volynets Julia, Dorokhova Daria Borys Grinchenko University of Kyiv

\section{INNOVATIVE LEARNING TECHNOLOGIES IN PUBLIC PRESCHOOL EDUCATION INSTITUTIONS: THEORETICAL ASPECT}

Summary. Each innovative pedagogical technology necessarily affects the internal environment of the preschool institution, and requires adaptation to changes in both the institution itself and the preschool teachers themselves. The article is devoted to the analysis of the topical issue of the present - the introduction of innovative learning technologies in public institutions of preschool education. The article highlights and theoretically substantiates the problem of revealing the theoretical foundations of the importance of this problem. The basic concepts of «innovation», «innovative learning technologies» are revealed. The result of innovative processes in preschool education is the use of innovations, both theoretical and practical, as well as those that are formed at the junction of theory and practice. The introduction of innovations usually means the transition to a new comprehensive program, or the emergence of a priority area (preschool institution with physical education and health and artistic and aesthetic). With the introduction of the updated Basic component of preschool education, the introduction of innovative learning technologies in preschool education becomes a key problem. The principle of integration, which provides for the interaction of educational sectors, requires reorientation of preschool teachers from the educational model of the educational process to the joint activities of adults and children, which is based on age-appropriate forms of educational work - experimentation, design, problem introduction, etc. In the framework of this study, innovative technologies as a pedagogical phenomenon are considered, the features of innovative processes in preschool education are analyzed. The analysis of innovative technologies of the organization of methodical work in an institution of preschool education is carried out. Pedagogical innovations must be put into practice; use new and active forms of work with preschool children, which are able to involve teachers in activities and dialogue, which involves a free exchange of views.

Keywords: readiness of the preschool teacher for innovative technologies, preschool teachers, establishments of preschool education, innovation, innovative learning technologies, methodical work.

$\Pi^{2}$ остановка проблеми. Дошкільна освіта е фондаментом освітньої системи країни і має велике сощіально-економічне значення, яке обумовлюеться необхідністю комплексної реалізації програми розвитку дітей дошкільного віку, а також надання їх батькам можливості участі у партнерській взаємодії з ЗДО. Тому розвиток даної сорери є пріоритетним напрямком державної політики, a, XXI століття, за правом, вважаємо століття розквіту інноваційних технологій, які активно впроваджуються в найрізноманітніші сорери людської діяльності, в тому числі й у сфреру освіти. Саме тому, професійна готовність дошкільного педагога до інноваційної діяльності дає можливість сучасному дошкільному педагогу конкурувати на ринку освітніх послуг.

Аналіз останніх досліджень і публікацій. Формування готовності педагогів до інноващійної діяльності висвітлили у своїх працях I. Бех, В. Бондар, Л. Ващенко, І. Дичківська, В. Загвязинський, М. Лещенко, І. Підласий, М. Чепіль тощо. Пробле- мі впровадження інноващійних технологій навчання в закладах дошкільної освіти присвятили свої дослідження Л. Артемова, Г. Белєнька, А. Богуш, Ю. Волинець, Л. Зданевич, О. Половіна, Т. Поніманська, О. Фунтікова та інші.

Актуальність проблеми, відсутність пї цілісного дослідження у сучасній науці та потреби практики зумовили вибір теми статті «Інноваційні технології навчання в державних закладах дошкільної освіти: теоретичний аспект».

Виділення невирішених раніше частин загальної проблеми. Здійснюючи аналіз Базового компоненту дошкільної освіти в Україні нами було розглянуто його ключові положення, зокрема було встановлено, що оновлений документ (від 12.01.2021) базується на компетентнісному підході [1]. Ключові компетенції базового компоненту дошкільної освіти продовжуються в Державному стандарті початкової освіти для певних освітніх галузей. Наступність між дошкільною та початковою освітою можна простежити через формування наскрізних 
навичок, загальних для дошкільної та початкової освіти: проявляти креативність та ініпіативу; керувати емоціями; висловлювати та обгрунтовувати власні думки; критично мислити; приймати рішення, вирішувати проблеми і працювати разом.

3 введенням в дію оновленого Базового компоненту дошкільної освіти впровадження інноваційних технологій навчання в ЗДО стає ключовою проблемою. Принцип інтеграції, що передбачає взаємодію освітніх галузей, вимагає переорієнтації дошкільних педагогів 3 навчальної моделі організації освітнього процесу на спільну діяльність дорослих і дітей, яка заснована на адекватних віку формах освітньої роботи - експериментування, проектування, введення проблемної ситуації та ін.

Мета статті - розкрити теоретичні основи впровадження інноваційних технологій навчання в державних закладах дошкільної освіти.

Виклад основного матеріалу. На сучасному етапі у дошкільній педагогіці відбувається низка оновлюючих процесів: оновлення, збагачення змісту освіти; запровадження новітніх підходів до організації роботи 3 дітьми дошкільного віку; запровадження інновацій різного рівня.

Нагальні вимоги до сучасних освітніх установ були сформульовані в Законі України «Про освіту» та конкретизовані в національній доктрині освіти, де виділено одне з головних завдань - стимулювання та розвиток інноваційних процесів. Інновації в освіті пов'язані із загальними процесами у суспільстві, глобальними проблемами, інтеграцією знань i форм соціального буття. Відтак, характерною ознакою сучасної педагогіки постає інноваційність здатність до оновлення, відкритість новому [8, с. 12].

Інновації в освіті є закономірним явищем, динамічним за характером і розвивальним за результатами, їх запровадження дозволяе вирішити суперечності між традиційною системою і потребами в якісно новій освіті. Сутнісною ознакою інноващії e ii здатність впливати на загальний рівень профресійної діяльності педагога, розширювати інноваційне поле освітнього середовища у навчальному закладі, регіоні. Як системне утворення інновація характеризується інтегральними якостями: інноваційний процес, інноващй̆на діяльність, інноваційний потенщіал, інноващійне середовище [8, с. 12].

Визначимо поняття «інновація», «інноваційні технології навчання». Інновація 3 англійського слова "Innovation», що означає «нововведення», "новина», "новаторство» [4]; також «інновацї̈» це i, як ідеї, і процеси, і засоби, і результати, взяті в єдності якісного вдосконалення педагогічної системи [10]. Інноваційні технологї̈ навчання мають за мету прищепити дошкільним педагогам дослідницькі уміння та сформувати активну, ініціативну, відповідальну та творчу особистість. У діяльності дошкільних педагогів особливо важливу роль має іх ініціатива і винахідливість, творчий підхід і прагнення до розробки й впровадження змін, цікавих ідей спрямованих на освітній процес та їх практична реалізація, а також умов, які створює для своїх працівників керівник ЗДО для здійснення інноваційної діяльності.

У своїй роботі ми послуговуємося бачення I. Дичківської, яка зазначає,що «інновація - це нововведення, зміна, оновлення; новий підхід, створення якісно нового, використання відомого в інших цілях» [7, с. 21]. У науковій літературі, окрім певних етапів розгортання інноваційних досліджень, також прийнято виділяти специфрічні для них закони та тенденції. Так, наприклад, I. Дичківська формулює такі закони перебігу інноваційного процесу: закон незворотної дестабілізації інноваційно-освітнього середовища. Суть закону в тому, що інноваційна творча діяльність змінюе свідомість педагогів, поляризуючи погляди в колективі;закон орінальної реалізащії інноваційного процесу. Цей закон, власне, нагадує думку Г. Гегеля про те, що все розумне колись стане дійсним; закон стереотипізації освітніх інновацій говорить нам, що на шляху досліджень і прагнень нового нас чекають пастки стереотипів і рутинізащії; закон циклового повторення, або закон зворотності освітніх інновацій, фріксує закономірність періодичних відроджень певних систем за нових умов [7, с. 38].

У педагогіці поняття «інновація» за I. Дичківською вживаються у таких значеннях: фрорма організації інноваційної діяльності; сукупність нових професійних дій педагога, спрямованих на вирішення актуальних проблем виховання і навчання з позиції особистісно-орієнтованої освіти; зміни в освітній практиці; комплексний процес створення, розповсюдження та використання нового практичного засобу в галузі техніки, технології, педагогіки, наукових досліджень; результат інноваційного процесу [7, с. 12].

Перетворення, що відбуваються в українській системі освіти, нащілюють дошкільних педагогів на необхідність перевірки існуючих форм, способів і методів освітнього процесу. Роль дошкільного педагога в процесі введення інновації в реальність закладу дошкільної освіти є досить значною. Ця роль вимагає багатосторонніх навичок (здатність діагностувати поточну ситуащію, обгрунтовувати зміни в галузі знань, нововведень). Творчість педагога в постійно мінливих умовах сучасної освіти $\epsilon$ неодмінним атрибутом розвитку. Творчий педагог пропонуе свої рішення, які стануть відповіддю на конкретні потреби вихованця, будуть підтримкою для його всебічного розвитку, сприятимуть зростанню привабливості закладу дошкільної освіти, а також особистості педагога. Результатом інноваційних процесів в державному закладі дошкільної освіти є використання нововведень, як теоретичних, так і практичних. Введення інновацій має на увазі, як правило, перехід на нову комплексну програму, або поява пріоритетного напрямку (ЗДО з фізкультурно-оздоровчим напрямком і художньо-естетичним тощо).

Перехід пов'язаний з рядом перетворень: зміна території (наприклад, організація спеціалізованих спортивних майданчиків, футбольного поля тощо); відкриття нових кабінетів оздоровчої спрямованості (масажного, фрізіотерапії, лікувальної фрізкультури); введення нових штатних одиниць медичних працівників; створення студій образотворчої діяльності, театрально-ігрової; організація додаткової освіти; апробація авторських програм, технологій i методик; впровадження інноващійних педагогічних технологій [5]. До числа сучасних освітніх технологій можна віднести: здоров'язберігаючі технології; технології проектної діяльності; технології досліднищької діяльності; розвиваючі технології; корекційні технології; інформаційно-комунікаційні технології; особистісно-орієнтовані технології; ігрові технології. 
Вибір інноваційної педагогічної технології педагогом ЗДО багато в чому залежить від того, наскільки педагогічна технологія сприймаеться й ідентифікуеться дошкільним педагогом, наскільки вона відповідае його особистісним якостям і психологічним характеристикам, наскільки він має уявлення про призначення технології, формах і методах, при яких їх реалізація в освітньому процесі буде найбільш ефективною. 3 огляду на це - одним 3 важливих завдань методичної роботи в ЗДО є надання своєчасної допомоги дошкільному педагогу з метою удосконалення його професійної підготовки. Методична робота - це основний вид освітньої діяльності, що представляе собою сукупність заходів, що здійснюються адміністрацією ЗДО, дошкільними педагогами 3 метою оволодіння методами і прийомами освітньої роботи, творчого застосування їх у різних формах діяльності з дітьми дошкільного віку, пошуку нових, найбільш ращіональних і ефективних форм і методів організації, проведення та забезпечення освітнього процесу.

На заклад дошкільної освіти в сучасних умовах розвитку нашого суспільства покладаються дуже відповідальні соціальні завдання - навчати, виховувати і готувати до життя покоління людей, праця, талант, ініціатива і творчість яких будуть обумовлювати соціально-економічний, науково-технічний i моральний прогрес суспільства [1]. На даному етапі слід відшукати такі важелі, за сприяння яких можна впоратися з негативними явищами: формалізмом, пасивністю деяких дошкільних педагогів. Основоположними з цих важелів е активізація людського фактору в освіті, стимулювання творчого потенціалу педагогів і педагогічних колективів ЗДО. Сучасні реалії, об’єктивні потреби поліпшення системи освіти, виховання і розвитку дошкільнят визначають необхідність швидкого зростання ролі і значущості методичної роботи в ЗДО, роблять науковий аналіз і практичне вдосконалення ціеї роботи актуальною проблемою, що позначається і на досягненнях, і результатах роботи педагогів.

Методична робота в сучасному державному ЗДО має бути спрямована на підвищення професійної компетентності дошкільного педагога, а також формування дослідницьких умінь, орієнтування в інформаційному просторі, володіння IКT. Безсумнівно, методична робота в освітньому процесі ЗДО повинна бути орієнтована на досягнення і підтримання високої якості освітнього процесу, заснованого на сучасній педагогічній парадигмі, новому педагогічному мисленні, індивідуальному стилі професійної діяльності дошкільного педагога, сучасних педагогічних технологіях (інноваційні технології та методики в галузі дошкільної освіти: «Спадщина Софіï Русової («Український дитячий садок»); «Педагогіка Марії Монтессорі («Будинок вільної дитини»); «Вальдорфська педагогіка («Вальдорфський дитячий садок»); «Система освіти «Довкілля»; «Діагностична методика Т. О. Піроженко «Мовленневе зростання дошкільника»; «Технологія фрізичного виховання дітей М. Єфименка («Театр фрізичного розвитку та оздоровлення дітей»); «Технологія розвитку творчої особистості Г. Альтшуллера. Теорія розв'язання винахідницьких завдань»; «Методика використання схем-моделей для навчання дітей описових розповідей»; «Особистісний розвиток дитини засобами взаемодії різних видів мистецтва»; «Ху- дожній розвиток дітей дошкільного віку в педагогічному процесі закладу дошкільної освіти»; «Технологія психолого-педагогічного проектування»; «Спадщина Василя Сухомлинського»; «Методика навчання дітей читання М. Зайцева»; «Методика навчання дітей раннього віку Глена Домана»; «Розвивальні ігри Нікітіних: кубики, гра типу «Танграм»; «Педагогіка Амонашвілі»; «Читання за методикою Л. Шелестовою; «Методика Кьюзенера (логіко-математична діяльність дошкільника)»; «Ггромастер» Миколи Шутя тощо).

Основна мета методичної роботи державного ЗДО - досягнення високої ефективності освітнього процесу шляхом розширення професійнопедагогічного кругозору i реалізації творчого потенціалу всіх дошкільних педагогів. До найбільш ефективних в методичній роботі з педагогічним колективом вважаємо такі інноваційні технології навчання, як: інтерактивний метод, технологія саморозвитку, проектна діяльність педагогів тощо. Запроваджені методи роботи з педагогічним колективом спонукають дошкільних педагогів до прояву творчості, ї ініціативності, самовдосконалення, вміння постійно вчитися, досягати спільних цілей ЗДО.

В. Березюк та О. Рудік пропонують індивідуальні та групові психотехнології для подолання бар'ерів в інноваційній діяльності. Групові психотехнології - учасники отримують допомогу в розвитку таких специфічних комунікативних навичок, як опис поведінки, передавання почуттів, активне слухання, конфрронтація. Для цього їм пропонують такі практичні вправи: «Індивідуальне малювання», «Парне малювання», «Групове малювання», «Пластиліновий світ». Відкритий показ - форма навчання педагогів і розповсюдження передового досвіду. Семінар-практикум, методичне об'єднання - проводяться для більш глибокого і систематичного вивчення проблем педагогіки, психології, методики; теоретичний матеріал підкріплюеться прикладами 3 практики, показом окремих прийомів та способів роботи. Вдосконалюеться професійна майстерність вихователів та інших працівників закладу дошкільної освіти у певному виді діяльності, розвиваеться творчість та фонтазія. Дискусія - розглядання, дослідження, обговорення проблемного питання, де кожен мае висловити власну думку, вчитися відстоювати іï, доводити свою точку зору. Творчі групи - створюються добровільно, коли необхідно вивчити передовий досвід, нову методику або розробити перспективну ідею. Кожен член групи самостійно вивчає закріплене за ним питання, готуе коротку інформацію. Потім усі обмінюються думками, дискутують, пропонують варіанти та впроваджують у практику своєї роботи. Спільне творче опанування нового відбуваеться у три-чотири рази швидше, ніж іншими засобами. "Круглий стіл" під час обговорення будь-яких питань виховання і навчання дошкільників розміщення учасників по колу дозволяе поставити всіх у рівне становище, забезпечити їх взаємодію. Брифбінг - це зустріч, на якій коротко викладаеться позиція щодо одного з нагальних питань. Ї̈̈ може проводити директор або вихователь-методист, який заздалегідь готуеться до відповіді на запитання 3 визначеної теми і дозволяе максимально залучити вихователів. Художня скринька - до скриньки, залежно 
від педагогічних завдань, можна покласти репродукції творів зображувального мистецтва, дротографріï, малюнки предметів, тварин, явищ природи i тощо. Матеріали скриньки можуть бути основою виставки. Творча вітальня - форма організації взаємодії педагогів відповідно до їх інтересів і уподобань. Створюе атмосфреру вільного, невимушеного спілкування. Огляд-конкурс - спосіб перевірки профресійних знань, умінь, навичок, педагогічної ерудищії. Передбачає можливість ощінювати результати шляхом порівняння своїх можливостей з можливостями інших. Телатичні виставки презентація наочних матеріалів: малюнків, виробів, літератури, посібників; сприяе збагаченню знань, є змістовою формою обміну досвідом між педагогами. Музичний салон - одна з форм естетичного розвитку, духовного спілкування педагогів, батьків і дітей, збереження найкращих народних традищій, звичаїв. Прийом формування сприятливого мікроклімату в колективі [9, с. 73].

Таким чином, важливим методичним аспектом впровадження інноваційних технологій навчання є готовність дошкільного педагога до інноващійної діяльності. Дошкільний педагог має бути вмотивованим до участі в інноваційній діяльності, вміти самооцінювати свої можливості, бути творчою особистістю, педагогом-дослідником, вміти рефрлексувати.
Висновки і пропозиції. Отже, для успішного здійснення інноваційної діяльності в державних ЗДО ми визначаємо готовність дошкільного педагога до неї та створення належних умов з боку керівництва. Також зазначимо, що основна мета впровадження інноваційних технологій та їі організація у роботу державних ЗДО - $є$ допомога дошкільним педагогам у підвищенні їх профресійної компетентності. Постійний зв'язок змісту методичної роботи 3 результатами їх роботи забезпечує безперервний процес вдосконалення професійної майстерності. Традиційні фрорми методичної роботи, в яких головне місце відводилося доповідям, виступам втратили своє значення через низьку їх ефрективності і недостатній зворотній зв'язок. Сьогодні треба використовувати нові, активні форми роботи, які здатні до залучення педагогів в діяльність і діалог, що передбачає вільний обмін думками.

Однак, представлена стаття не розкриває усього комплексу проблеми, яка потребує вирішення. Отже, перспективами подальших розвідок у даному напрямку є розробка методології організації впровадження інноваційних технологій навчання в державних закладах дошкільної освіти та висвітлення педагогічних умов для підвищення ефективності інноваційної діяльності.

\section{Список літератури:}

1. Базовий компонент дошкільної освіти (2021). URL: https://mon.gov.ua/ua/osvita/doshkilna-osvita/bazovijkomponent-doshkilnoyi-osviti-v-ukrayini (дата звернення: 20.04.2021).

2. Беленька Г.В. Теоретико-методологічні засади формування професійної компетентності вихователів дошкільних навчальних закладів в умовах ступеневої підготовки : автореф. дис. ... докт. пед. наук. Київ, 2012.38 с.

3. Волинець Ю.О., Стаднік Н.В. Упровадження інформаційних технологій у процесі професійної підготовки майбутніх дошкільних педагогів. Народна освіта. 2020. Вип. 2(41). URL: https://www.narodnaosvita.kiev.ua/ ?page_id=6229 (дата звернення: 20.04.2021).

4. Гільбух Ю.З., Дробноход М.I. Інноваційний експеримент у школі. На допомогу початкуючому дослідникові. Київ, 1994. С. 3.

5. Дитина: Освітня програма для дітей від двох до семи років / наук. кер. проекту В.О. Огнев’юк; авт. кол.: Г.В. Белєнька, О.Л. Богініч, В.М. Вертугіна [та ін.]; наук. ред. Г.В. Белєнька. Київ : Київ. ун-т ім. Б. Грінченка, 2020. 440 с.

6. Дитина в дошкільні роки: комплексна додаткова освітня програма / авт. кол. ; наук. кер. К.Л. Крутій. Запоріжжя : ТОВ «ЛІПС» ЛТД, 2011. 188 с.

7. Дичківська I.M. Інноваційні педагогічні технології : навчальний посібник. Київ : Академвидав, 2004.352 с.

8. Інновації в освіті: інтеграція науки і практики : збірник науково-методичних праць / за заг. ред. О.А. Дубасенюк. Житомир : Вид-во ЖДУ ім. І. Франка, 2014. 492 с.

9. Інноваційні технології в ДНЗ / Березюк В.С., Рудік О.А. Харків : Вид. група «Основа», 2017. 224 с. (Серія «ДНЗ. Керівнику»).

10. Підласий І.П., Підласий А.І. Педагогічні інновації. Рідна школа. 1998. № 12. С. 3.

\section{References:}

1. The basic component of preschool education (2021). URL: https://mon.gov.ua/ua/osvita/doshkilna-osvita/bazovijkomponent-doshkilnoyi-osviti-v-ukrayini (accessed 20 April 2021).

2. Belenka G.V. (2012). Theoretical and methodological principles of formation of professional competence of educators of preschool educational institutions in the conditions of degree preparation: author's ref. dis. ... Dr. ped. Science. Kyiv, 38 p.

3. Volynets J.O., Stadnik N.V. (2020). Introduction of information technologies in the process of professional training of future preschool teachers. Public education, issue 2(41). URL: https://www.narodnaosvita.kiev.ua/?page_id=6229. Name from the screen (accessed 20 April 2021).

4. Gilbukh Y.Z., Drobnokhod M.I. (1994). Innovative experiment in school. To help the novice researcher. Kyiv, p. 3.

5. Child: Educational program for children from two to seven years / scientific manager of the project V.O. Ognevyuk; avt. kol.: G.V. Belenka, O.L. Boginich, V.M. Vertugina [mystery]; scientific editor G.V. Belenka. Kyiv: Kyiv Univ. Grinchenko, 2020. 440 p.

6. The child in preschool years: a comprehensive additional educational program (2011) / ed. count ; Science. ker. K.L. Cool. Zaporozhye: LLC "LIPS" LTD, 188 p.

7. Dychkivska I.M. (2004). Innovative pedagogical technologies: a textbook. Kyiv: Akademvidav, 352 p.

8. Innovations in education: integration of science and practice: a collection of scientific and methodical works / for general. ed. O.A. Dubasenyuk. Zhytomyr: ZhSU Publishing House. I. Franko, 2014. 492 p.

9. Innovative technologies in schools / Berezyuk V.S., Rudik O.A. Kharkiv: Ed. Osnova group, 2017. 224 p. (Series "School. Head").

10. Podlasy I.P., Podlasy A.I. (1998). Pedagogical innovations. Native school, no. 12, p. 3. 